GadjahMadaInternational Journal of Business

September-December 2005, Vol. 7,No. 3,pp. 391—427

\title{
AN ASSESSMENT OF MICROFINANCE INSTITUTION PERFORMANCE The Importance of Institutional Environment ${ }^{*}$
}

\section{Lincolin Arsyad}

This paper aims to assess the performance of Village Credit Institutions (Lembaga Perkreditan Desa or LPD) in Gianyar district, Bali province, Indonesia and its affecting factors - particularly its institutional environment. The performance indicators assessed include financial indicators (such as portfolio quality, leverage, capital adequacy ratio, productivity, efficiency, profitability, and financial viability) and outreach of the LPDs. Institutions here refer to the rules or procedures that shape howagents (people) interact and the organizations that implement the rules and codes of conduct to achieve desired outcomes. Based on data from financial reports of 174 LPD of Gianyar district in 1999 and 2001, interviews with some stakeholders (clients, chairmen, and member of commissioner board) of the LPDs, and using descriptive analysis approach, this paper reveals that the LPDs have achieved a good performance indicators and been sustainable, and the good performance and sustainability have been very much influenced by institutional environment which includes both formal and informal institutions.

Keywords: financial performance; informal institutions; microfinance institutions; outreach; sustainability

* This Article is based on a section of Ph.D. thesis of the author at Flinders University, Adelaide, Australia, 2005. Many thanks go to two anonymous referees that have made extremely helpful comments. I have also profited from comments by Susanne Schech and Joe William from Development Studies and Department of Business Economics, Flinders University, Adelaide, Australia, respectively. 


\section{Introduction}

Microfinance ${ }^{1}$ institutions have evolved as an economic development tool intended to benefit low-income people since late 1990s. Ledgerwood (1999: 34) points out that the goals of microfinance institutions as development organizations is to service the financial needs of unserved or underserved markets as a means of meeting development objectives such as to create employment, reduce poverty, help existing business grow or diversify their activities, empower women or other disadvantaged population groups (poor people or low-income people), and encourage the development of new business. In short, microfinance institutions have been expected to reduce poverty, which is considered as the most important development objective (World Bank 2000). However, the positive impacts of microfinance institutions on the socioeconomic welfare of the poor can only be attained and sustained if the institutions can achieve a good financial and outreach performance.

The aim of this paper is to assess the performance of the Village Credit Institutions (LPDs) of Gianyar district in Bali and the influence of institutions on the performance. The performance analysis focuses on financial indicators and outreach. The financial indi- cators include portfolio quality, leverage, capital adequacy ratio, productivity, efficiency, profitability, and financial viability. The outreach indicators cover clients and staff outreach, loan outreach and saving/deposits outreach. Institutions here are defined as the rules or procedures that shape how agents (people) interact and the organizations that implement the rules and codes of conduct to achieve desired outcomes (Brinkerhoff and Goldsmith 1992:371; North 1991:97; North 1990: 3, World Bank 2002: 6). Institutions are classified in two types which are formal and informal institutions (North 1991: 97; World Bank 2002: 6). Formal institutions include the rules written into the law and regulations by government, rules codified and adopted by private institutions, and public and private organizations operating under public law. Informal institutions, which often are operating outside the formal legal system, reflect unwritten codes of social conduct such as social norms and sanctions and using social mechanisms to creditworthiness based on the reputation of the agents involved.

The approach of this study is a case study analysis. The selection of LPDs of Gianyar as a case for this study is based on some rationales. Scapens (1990: 272-273) suggests three rationales in selecting a case.

\footnotetext{
${ }^{1}$ The Asian Development Bank (ADB) defines microfinance as the provision of a broad range of financial services such as deposits, loans, payment services, money transfers, and insurance to poor and low-income households and their micro-enterprises (ADB 2000. Finance for the Poor: Microfinance Development Strategy. Manila: Asian Development Bank).
} 
First, the case selected can represent a critical case that directly exhibits and addresses key issues that have been well identified and discussed in the subject area under study. This critical case can be used to determine whether a theory's propositions are correct or whether some alternative set of explanations need to be developed and might be more relevant. Second, the case can represent an extreme case or a unique case that extends the subject area beyond the limits of its previous observation in circumstances that differ from scenarios previously considered. Third, the exploratory case ${ }^{2}$ may be selected for the examination of a subject area on which there is little prior theory or evidence available. Yin (2003:42) adds two more rationales, that is, the revelatory case and the longitudinal case. The revelatory case exists when an investigator has an opportunity to observe and analyze a phenomenon previously inaccessible to scientific investigation and the longitudinal case refers to a study of the same case at two or more different points in time.

From those perspectives, the selection of LPD as a case is an exploratory one. It is 'exploratory' because even though the LPD is considered as a success microfinance institution in Indonesia by some scholars (Chaves and Gonzales-Vega 1996; Christen et al. 1995), the LPD -in particular the LPDs of Gianyar-represents a microfinance institution that is little understood from the point of view of its sociocultural context, its management, and other factors influencing its performance and sustainability. In addition, the selection of Gianyar district was also influenced by the ease of access of the researcher to the sample region.

The dataset used as the basis for calculation and analysis of the indicators are mainly based on financial reports of 174 LPDs of the Gianyar district in 1999 and 2001. The data from income statements includes operating income, operational cost (expenses), labor cost (salary), net income (profit), and provision for loan losses. From balance statements, it is possible to ascertain the total assets, current assets (loan outstanding and credit default), fixed assets, client savings, client time deposits, capital, and equity. In addition, other related data such as the number of client data (including borrowers, savers, and depositors), the data on population and Gross Regional Domestic Product (GRDP) of Gianyar district and its subdistricts from the Central Board of Statistics of Gianyar district are also used in this analysis.

Even though a case study analysis does not seek to mimic the generalizable findings from a questionnaire survey of a large sample of respondents from a population, it nonetheless offers the prospect of theoretical rather than statistical generalizations. When case studies are properly undertaken,

\footnotetext{
${ }^{2}$ Yin uses the terms 'representative' or 'typical' case (see Yin 2003: 42)
} 
they should not only fit the specific individual, group, or event studied, but also offer insights that can be transferred to similar individuals, groups, and events (Berg 1998: 218). The case that provides convincing observations and explanations will be retained as a key source of insight into concepts, their relationship and an explanatory of cause and effect at the micro level. It offers the policy makers an understanding of individual differences and unique, particular processes at the individual enterprise level -something that is inaccessible to the decision maker who relies solely upon the necessarily general findings of statistically survey results that can only provide predictions of majority attitudes or behavior at macro-superficial level of research questions to which any survey is limited. Thus a case study of the type offered here provides an expansion of our understandings that can be obtained from empirical observations by offering rich detail in an actual enterprise context (Scapens 1990).

The advantage of this case study research strategy lies in its revealing the microfinance institution as a unique fusion of social, cultural, and economic processes. "Scientifically" derived general laws and statistical generalizations from a large-scale survey may or may not apply to the case of a particular organization and may not explain its peculiar circumstances. Understanding and explanation on an enterprise's success or failure and identification of its available strategic alternatives must ultimately come from addressing the unique holistic characteristics of that particular case (Scapens 1990). The application of case study analysis to microfinance institutions offers the prospect of capturing situational data and perspective that may prove crucial to the likely effectiveness of any policies or strategies formulated for the institutions. It is argued that this type of analysis provides a safeguard against the tendency to ask the wrong questions, to ignore important variables and relationships, or to simplistically model a complex entity and its processes (Fuller and Parker 2002). Instead, in the microfinance institution context, field research can offer the possibility of better recognizing the distinctive qualities, inherent limitations and potential strategic advantages of a microfinance institution.

\section{Performance Measurement of Microfinance Institution}

Microfinance institution is a financial intermediary. As a financial intermediary aiming to give a better access for credit to low-income people, the institution is expected to be financially viable in achieving its selfsustainability. Consequently, the performance measurement in part has to be based on its financial viability. ${ }^{3}$ The cost efficiency should be the primary

\footnotetext{
${ }^{3}$ Financial viability refers to the ability of a microfinance institution to cover its costs with earned revenue
} 


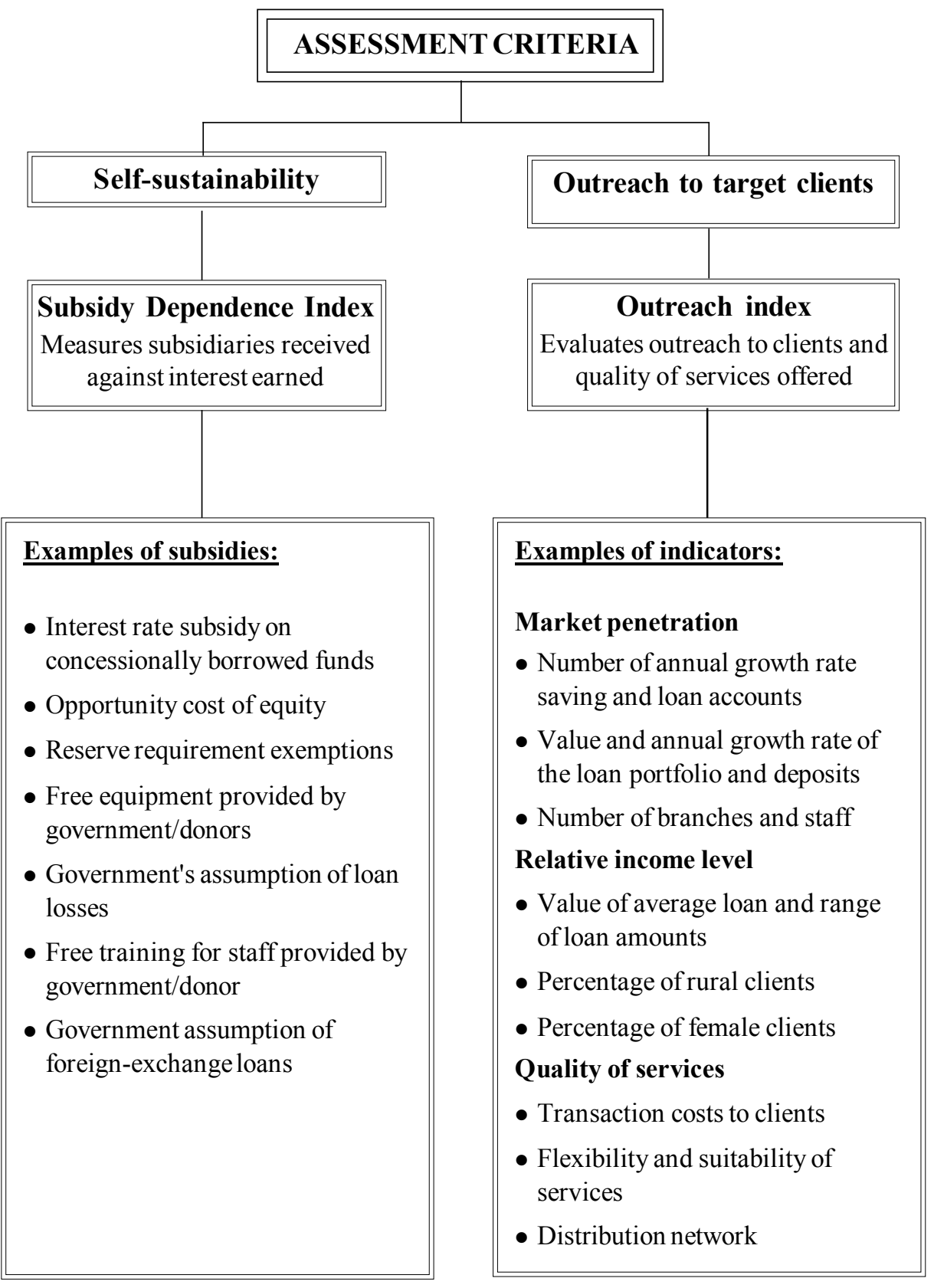

Source: Yaron et al. (1997) 
concern in order to achieve its selfsustainability of the institution (Khandker 1998). However, in the literature, performance measurement of microfinance institution is based not only on self-sustainability but also on the outreach of the institutions, measured by the coverage of target households and the extent of services they receive. Outreach indicators are considered as proxies for impacts of microfinance institutions on development (Yaron et al. 1997). The twin criteria of self-sustainability and outreach -which are complementaryhave been then the yardstick of microfinance performance evaluation (Chaves and Gonzales-Vega 1996; Christen et al. 1995; Ledgerwood 1999; Yaron 1992; Yaron 1994; Yaron et al. 1998).

The assessment framework of Yaron can be seen in Figure 1 (Yaron et al. 1997: 90). The first criterion is self-sustainability, which can be achieved when the return on equity, net of any subsidy received, equals or exceeds the opportunity cost of the equity funds. Subsidy dependence is the inverse of self-sustainability (Yaron 1992). Traditionally, microfinance institutions have been sustained by various types of implicit or explicit subsidies to continue operations.

The most common subsidies have been differences between the market interest rate and interest rates paid on concessional borrowing from the state or donor, state assumption of foreign exchange losses on loans denominated in foreign currencies, obligatory deposits by other financial or public institutions at below-market rate, direct reimbursement by the state or donor of some or all operating costs, and exemption from reserve requirements or forced investment (Yaron 1994). In the self-sustainability approach donations (subsidies) cover start-up costs and fund experiments meant to find innovations that reduce the cost of supply so much that revenue from clients can cover costs in the long run (Schreiner 2002). This is the case of the Village Credit Institutions (LPD) of Bali which only receive a starting capital of Rp10 million from Provincial Government of Bali for each institution according to provincial regulation (Government of Bali 2002). ${ }^{4}$ Since the LPD does not receive interest rates subsidy, it is not necessary to calculate the subsidy dependence index (SDI). As stated by Yaron (1994: 57), the SDI measures the percentage increase in the average on-lending interest rate required to compensate for eliminating subsidies, including the subsidy a microfinance institution receives through paying interest below the market rate on its borrowed funds (mostly rediscounting facilities with the central bank or soft loans from donors). However, other indicators of self-

\footnotetext{
${ }^{4}$ The LPDs of Bali rely on savings and deposits rather than on credit and grants as their source of refinancing (BI and GTZ 2000).
} 
Arsyad -An Assessment of Microfinance Institution Performance

Table 1. Microfinance Assessment Performance Approaches

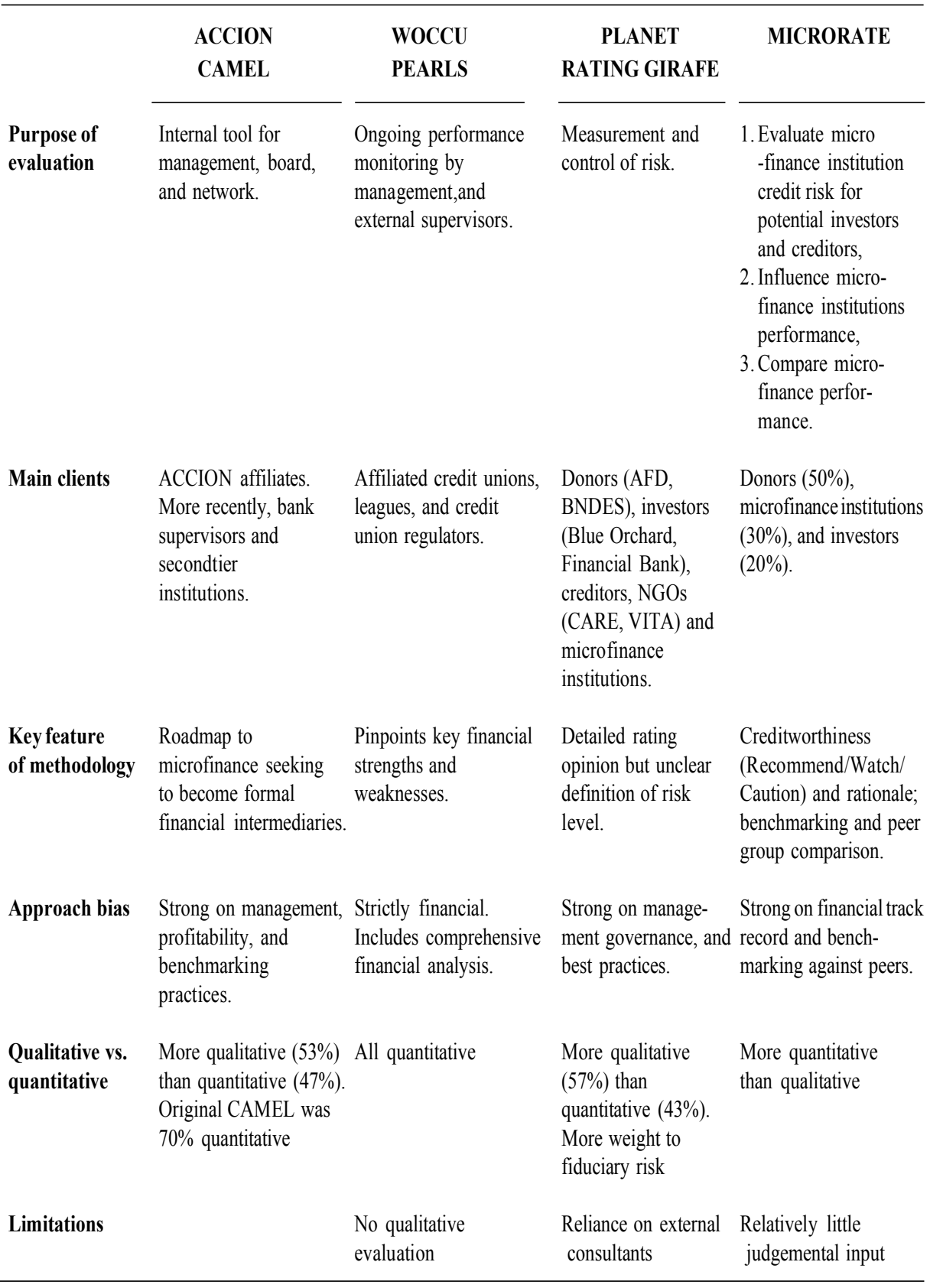

Source: CGAP (2001) 
sustainability such as operational selfsufficiency and financial self-sufficiency are calculated in this study.

The second criterion is the number of clients served and the variety of financial services provided. This is an outreach objective, which consists of scale and depth of outreach. ${ }^{5}$ Scale of outreach refers to the number of clients served with different types of instrument and the depth of outreach refers to the type of clients reached and their level of poverty.

Based on these two important criteria -the self-sustainability and the outreach-several performance assessing techniques have been developed in 1990s (CGAP 2001). The key features of some important approaches are presented in Table 1. First, ACCION ${ }^{6}$ Approach which adopts the original CAMEL methodology to evaluate U.S. commercial lending institutions (CGAP 2001). CAMEL is the acronym of Capital adequacy, Asset quality, Management, Earnings, and Liquidity. While the ACCION CAMEL issues a composite score, similar to a rating, it is not meant to measure credit risk. The final score ranges from 0 to 5 , or D to AAA. A microfinance institution scoring below 2 should be operating a lending business. Scores from 2 to 3 indicate microfinance institution with fundamental weaknesses that must be corrected. The purpose of this tool is to strengthen management and generate a common framework for evaluating and comparing the performance ACCION affiliates across countries such as in Latin American countries.

Second, the World Council of Credit Unions (WOCCU) - a nonprofit organization that promotes the development of financial cooperatives, headquartered in Madison, Wisconsin-uses PEARLS in assessing the performance of microfinance institution (CGAP 2001). The PEARLS is a set of 45 ratios used to evaluate and monitor the financial stability of credit unions within WOCCU, especially for use in its institutional strengthening programs. PEARLS are grouped under six areas of financial performance: protection, effective financial structure, asset quality, rates of return and costs, liquidity, and signs of growth (PEARLS).

The PEARLS methodology is driven by financial performance. However, PEARLS does not explicitly address management, though an institution's financial performance obviously says a great deal about its management.

\footnotetext{
${ }^{5}$ Outreach is measured by hybrid index comprising several indicators, such as the number of clients, the amount of savings and the average value of savings accounts, the average of loans size (as a proxy for income level of the clientele, the number of branches and village post/units, the variety of financial services offered, the percentage of target population served, the annual growth of microfinance institutions assets over recent years in real terms, and women's participation (where social norms discriminate against women).

${ }^{6}$ ACCION International is an organization aims to reduce poverty in North and South America by providing small loans. It was founded in 1961 and based in Boston, Massachusetts.
} 
Arsyad-An Assessment of Microfinance Institution Performance

Table 2.The Performance Indicators of Microfinance Institutions (Ledgerwood's Approach)

\begin{tabular}{|c|c|}
\hline Areas & Indicators \\
\hline Portfolio quality & $\begin{array}{l}\text { - Repayment rates } \\
\text { - Portfolio quality ratios (arrears rate, portfolio at risk, } \\
\text { ratio of delinquent borrowers) } \\
\text { - Loan loss ratios }\end{array}$ \\
\hline Productivity and efficiency & $\begin{array}{l}\text { - Productivity ratios (number of active loans per credit } \\
\text { officer, average portfolio outstanding per credit of- } \\
\text { ficer, amount disbursed per period per credit officer) } \\
\text { - Efficiency ratios (operating cost ratio, cost per unit of } \\
\text { currency lent, cost per loan made) }\end{array}$ \\
\hline Financial viability & $\begin{array}{l}\text { - Financial spread } \\
\text { - Operational self-sufficiency } \\
\text { - Financial self-sufficiency } \\
\text { - Subsidy Dependence Index }\end{array}$ \\
\hline Profitability & $\begin{array}{l}\text { - Return on Assets Ratio } \\
\text { - Return on Business Ratio } \\
\text { - Return on Equity Ratio }\end{array}$ \\
\hline Leverage $\&$ capital adequacy & $\begin{array}{l}\text { Leverage (debt to equity ratio) } \\
\text { - Capital adequacy standards }\end{array}$ \\
\hline Scale, outreach, and growth & $\begin{array}{l}\text { Clients and staff (number of clients, number of staff, } \\
\text { number of branches, percentage of total target clien- } \\
\text { tele serviced, etc.) } \\
\text { - Loan outreach (number of currently active borrowers, } \\
\text { total balance outstanding loans, average outstanding } \\
\text { portfolio, average disbursed loans size, average dis- } \\
\text { bursed loans size as a percentage of GDP per capita, } \\
\text { value of loans per staff member, number of loans per } \\
\text { staff member, average outstanding loan size, average } \\
\text { outstanding loan size as a percentage of GDP per } \\
\text { capita, etc.) } \\
\text { - Savings outreach (total balance of voluntary savings } \\
\text { accounts, totalannual average savings as a percentage } \\
\text { of annual average outstanding loan portfolio, number } \\
\text { of current voluntary savings clients, value of average } \\
\text { savings account, number of savers per staff member, } \\
\text { average savings deposits as a percentage of GDP per } \\
\text { capita, etc.) }\end{array}$ \\
\hline
\end{tabular}

Source: Ledgerwood (1999), tabulated by author 
Gadjah Mada InternationalJournal of Business, September-December 2005, Vol. 7, No.3

Third, PlaNet Rating-a branch of PlaNet Finance, an international nonprofit organization based in Paris-uses GIRAFE Rating in assessing the performance of microfinance institutions (CGAP 2001). GIRAFE's 26 indicators are grouped under six areas of risk: governance and decision making process, information and management tools, risk analysis and control, assets including loan portfolio, funding (equity and liabilities), and efficiency and profitability. Among other approaches, GIRAFE gives the most weight to "fiduciary" risk-how institution is governed, and whether it may fail to meet investors' and shareholders' expectations because of inadequacies in systems, processes, and organization. The methodology focuses more on management than on risk. Fourth, the approach proposed by MicroRate (CGAP 2001), a limited liability company basedin WashingtonD.C. MicroRate's methodology focuses on how the various risks of microfinance institution operations affect an institution's creditworthiness. The main components of this methodology are (1) identifying key risk areas and their drivers; (2) comparing the microfinance institutions performance with that of its peers on an adjusted basis; and (3) making this information available to the market where possible. The key factors driving the evaluation are efficiency, asset quality, growth, and profitability. MicroRate has completed about 70 assessments so far, most of them in Latin America.
All of the four techniques presented above are applicable to assess the performance of microfinance institution. However, in selecting an assessment technique, some contextual factors must be considered, such as geographical context (appropriate benchmark in Latin America are not necessarily adequate for Asia and Africa), the maturity of the institutions (younger institutions may be incurring expansion costs without commensurate revenue and should not be compared to mature institutions), and the varying lending approaches that are used(Ledgerwood 1999). Performance indicators must be put in the context of where and how the different microfinance institutions are operating. Moreover, Ledgerwood argues that majority of the present assessment techniques are based on the assumption that most microfinance institutions are primarily lending institutions. Hence, she proposes an assessment technique in her book Microfinance Handbook published by the World Bank (1999) as presented in Table 2 .

Ledgerwood(1999) points out that this technique has been drawn from a number of microfinance institutions, both formal and semi formal, around the world. She points out that each of these performance indicators was chosen because they are useful in managing microfinance institutions (internal management) such as productivity and efficiency. Many of them (including financial viability, profitability, leverage and capital adequacy ratios, and 
scale, outreach, and growth) are also useful for external parties, such as investors or donors (Ledgerwood 1999: 205).

Considering the nature of the LPDs of Bali which were designed as financial intermediaries from the beginning and the ability of the LPDs to rely on savings and deposits rather than on credit and grants as their source of refinancing (Bank Indonesia and GTZ 2000), the availability of data, appropriateness in geographical context, and the end users of the assessment, Ledgerwood's approach seems to be the most appropriate one to be used in this study. The calculation technique of the indicators chosen in this study is provided in Appendix 1.

\section{Sociocultural Characteristics of Balinese}

The discussion on the sociocultural characteristics of Balinese is focused on the role of custom village (desa adat) and banjar as corporate groups (social system) on the social daily life of Balinese. This discussion is very useful in assessing the factors affecting performance of the Village Credit Institutions of Bali since some of these sociocultural factors, it is argued, have played a major role in the success of government programs such as family planning, small-scale industry training, and loan programs in Bali (Jayasuriya and Nehen 1989: 13; Warren 1991: 233) .
In Bali, besides administrative village (desa dinas), which is an element of government administration, there are also custom villages (desa adat). The administrative village in Bali and all over Indonesia was established by the Government of Republic of Indonesia through the Village Government Law No. 5/1979. This Law sets out to create uniform local administrative structure across Indonesia, with the stated objective of increasing the effectiveness of village administration and public participation in development policy (Warren 1991:238). However, custom village in Bali continued to exist as customary institutions and to function alongside their newly created administrative counterparts. However, the custom village is merely an association of people rather than a geographical or administrative unit. Warren (1993: 20) describes the custom village as "a corporate community sharing collective descent from the original village founders, who are worshipped as deified ancestors in the classic three village temples the so called the Kahyangan Tiga (The Three Holy Temples)."

There have been two fundamental differences between custom village and administrative village. The administrative village boundaries are determined along administrative lines and seldom coincide with those of the custom village. The custom village leader, the so-called Bandesa Adat, is elected and custom (adat) matters are decided 
Gadjah Mada InternationalJournal of Business, September-December 2005, Vol. 7, No.3

by the community (banjar) members in a democratic way in custom village meeting (paruman desa). In contrast, dinas (administrative) leaders, the socalled Perbekel or Kepala Desa, are appointed by, and responsible to, higher government levels such as subdistrict and district government level. According to Nordholt, in the Soeharto era villages maintained the right to choose their Perbekel or Kepala Desa in Bali, but in practice there were several restrictions (Nordholt 1991). Candidates were screened and sometimes there was pressure from above to eliminate candidates considered to be too independent or anti Golkar (state party).

The status of the custom village as a societal unit based on customary law was reinforced by the Bali Provincial Regulation of 1986 on the Status, Function, and Role of Custom Village in Bali (Government of Bali 1986). The custom village, as stated in article 5 of the Regulation, is a unit of societal customary law that is social and religious in nature. The village is the formal repository and guardian of customary law and ritual. Meanwhile, the function and role of custom village, as stated in article 6 of the Law, is to support the implementation of development program planned by government, especially in the religious, cultural, and social area; and to maintain and utilize the wealth of the custom village for the welfare of the people within the village. The ratification of the Provincial Regulation of 1986 reflects the Provincial Government's concern with reinforcing the role of community institutions, grounded in customary law and practice. The consideration of the regulation states that recognition of custom village because custom village has grown and developed for centuries and contributed significantly to the liveability of people in Bali.

The custom villages are usually subdivided into several banjar (hamlets) for densely populated regions (Warren 1993). However, Warren (1993) points out that in a large number of communities, especially those found in the mountain areas, banjar and custom village represent two associations covering a single bounded population. The banjar is the most basic association of people in custom villages (community) through which religious rites, mutual aid, cultural groups, local development projects and savings and credit activities are organized within close social ties. The members of banjar comprise adult men who can prove the completeness of their identity through a female partner -usually the wife, but sometimes sister, mother, or daughter. The focus of religious, social, and economic life of Balinese is the banjar, which effectively ${ }^{7}$ implements local custom (adat) in the name of the custom village, and organizes community life in Bali (Geertz and Geertz 1975; Hobart et al.

\footnotetext{
${ }^{7}$ The banjar is effective since its decisions involved the equal participation of all families and because it operates through consensus rather than confrontation (Mabbet 1985: 39).
} 
1996; Mabbet 1985). The Village Credit Institutions (LPDs) of Bali are rooted to the community and its establishment is grounded in the customary law and practice of its people (Arsyad 2005). The institutions are community financial institutions owned, managed, and used by the members of the custom village. The staff and clients of the LPDs, therefore, have to follow the customary rules (awig-awig) of custom village.

There have been two important duties of the banjar (Hobart et al. 1996: 86-88; Mabbet 1985: 38-40). First, among the most important duties of the banjar is the maintenance and restitution of the ritual purity of the custom village. Each banjar has specific tasks and ritual duties to fulfil for the benefit of the village temples. This indicates that the village as a religiousmagical authority is ranked above the secular autonomy of the banjar. However, banjar activities can be very mundane, for example, improving roads through community work or restoring the meetinghouse (bale banjar). The banjar is generally responsible for public institutions and even more for public welfare, which requires not only material support but also assistance in ritual matters.

Another important task of the banjar relates to social control and surveillance of the actions and behavior of the members in relation to the custom(Hobart etal. 1996). The banjar is legally permitted to impose sanctions against members who do not follow the rules (awig-awig), and fines may be incurred. For serious offences against the rules are punished by the exclusion of the wrongdoer from the banjar. This means that he/she loses his/her share of banjar ownership and the plot of land on which his/her family compound is built is withdrawn. $\mathrm{He} / \mathrm{she}$ also loses the right, in accordance to the custom, to a funeral in the village cemetery and subsequent cremation. $\mathrm{He} / \mathrm{she}$ becomes an outsider without security of the banjar community and must look for a new life far away from his native village. In relation to the LPDs, which are owned by the custom village, this kind of social sanctions could be applied to the staff or clients who violate the rules of the financial institution, such as corruption or failure to repay their credits properly (Oka 1999). In other words, the customary rules (awig-awig) can be expected to have a positive effect on the performance of the LPDs.

\section{The Structure and Growth of Gianyar District's Economy}

At present, Gianyar district with a population of 395,000 is one of the growth engines of Bali's provincial economy. According to Statistics of Bali Province 2001, with Gross Regional Domestic Product (GRDP) of Rp 2,307 billion, Gianyar was the fourth biggest contributor (12.16\%) to Bali province after Badung district (20.86\%), city of Denpasar (19.19\%), and Buleleng district (12.19\%). Based on GRDP per capita, Gianyar was ranked third after Badung district and 
Gadjah Mada InternationalJournal of Business, September-December 2005, Vol. 7, No. 3

Table 3. Selected Economic Indicators of Gianyar District of Bali Province 1997 and 2001

\begin{tabular}{lcccc}
\hline \multicolumn{1}{c}{ Indicators } & & $\mathbf{1 9 9 7}$ & & $\mathbf{2 0 0 1}$ \\
\cline { 1 - 1 } $\begin{array}{l}\text { - Gross Regional Domestic Product at current price (bil- } \\
\text { lion Rp) }\end{array}$ & & 1,171 & & 2,307 \\
- GRDP per capita (million Rp) at current price & & 3 & & 5.8 \\
- Rate of economic growth at constant price 1993 (\%) & & 6 & & 4.5 \\
- Share of manufacturing sector in GRDP (\%) & & 19 & & 20 \\
- Share of agricultural sector in GRDP (\%) & & 17 & & 16 \\
- Share of trade, restaurants and hotels in GRDP (\%) & & 29 & & 29 \\
- Inflation rate (\%) & & 10.3 & & 11.5
\end{tabular}

Sources: Gianyar in Figures 2000 (CBS of Gianyar District 2000); Socio-economic Profile of Gianyar Population 2001 (CBS of Gianyar District 2002); Regional Economic-Financial Statistics of Bali 2001 (Bank Indonesia 2002)

city of Denpasar in the same period. During Indonesian economic crisis from 1997 until 1999, the Gianyar economy still experienced a positive economic growth. Gianyar economic growth rates were 6 and 4.5 percent per annum in 1997 and 2001 respectively. Its economic growth rate in 2001 was higher than Bali and national average growth rate of 3.4 and 3.3 percent per annum respectively.

The steady economic growth of Gianyar district over the period between 1997 and 2001 was partly due to the Gianyar economy relying highly on small-scale industries (handicraft industries) and tourism-related sectors that were not influenced by the condition of the domestic economy. ${ }^{8}$ The small-scale industries that did not rely on raw material or heavy capital imports (which is the case of Gianyar's small-scale industries) even largely benefited from the economic crisis due to rupiah depreciation (Rice et al. 2002).

The important role of small-scale industries in Gianyar economy was indicated by the share of manufacturing ${ }^{9}$ in the GRDP of Gianyar (see Table 3 ). The textile, leather products and footwear, and wood products and other wood products sub-sectors are the predominant industries in Gianyar dis-

\footnotetext{
${ }^{8}$ Data from Central Board of Statistics (CBS) of Bali Province reveals that the number of foreign tourist arriving in Bali increases from 1,187,153 in 1998 to 1,355,799 in 1999 (CBS of Bali, Bali in Figures 1999).

${ }^{9}$ According to the classification of the Central Board of Statistics of Indonesia (CBS 2001), manufacturing sector consists of oil and gas manufacturing and non-oil and gas manufacturing. Non-oil and gas manufacturing consists of several sub-sectors such as textile, leather products and footwear, and wood products and other wood products.
} 
trict. The district had only 74 large and medium sized industrial establishments, but boasted 25,100 small-scale industrial establishments which employed 70,914 workers accounted for 88 percent of total employment in manufacturing sector [Central Board of Statistic (CBS) of Gianyar 2000]. These small-scale industries are concentrated in four centres in Gianyar which are Sukawati, Ubud, Tegallalang, and Gianyar subdistricts. During the economic crisis, those smallscale industries were still able to produce and export their products, and in turn contribute to the economic growth of Gianyar.

The economic structure of Gianyar district is similar to the structure of provincial economy. This similarity supports Gianyar district as the case of this study. Then it is expected that the findings of this study will also be able to describe the nature of the LPD in Bali province. Gianyar's economy is dominated by three main sectors manufacturing, agriculture, and trade, restaurants and hotels sector- which contribute about 65 percent to GRDP of Gianyar (see Table 3). The remaining 35 percent were contributed by other several sectors, including mining and quarrying, construction, transportation and communication, finance, rent and business services, and other services. However, in contrast to other districts, the manufacturing sector is the largest contributor to Gianyar's economy. In 1997, the contribution of this sector was about 19 percent, increasing to 20 percent by 2001 . This figure is much higher than the Bali provincial level of 8.5 percent (CBS of Bali 2001). The total contribution of the tourism related sectors was greatest with 29 percent in both 1997 and 2001. The increasing contribution of the light industry and service sector was accompanied by the decreasing contribution of the agricultural sector, which decreased from 19 percent in 1997 to about 16 percent in 2001. This figure was lower than the Bali provincial level of 19.1 percent. These figures demonstrate that the economy of Gianyar is based on light industry and service economy, indicating that the economic transformation from agricultural-based to light industrial and services-based economy which is occurring at a slower rate in Bali province has already happened in Gianyar district.

Based on all of the figures discussed above, it can be presumed that Gianyar's macro-economy provides a good opportunity for economic and business activities. The trend of economic growth that accompanied economic structural transformation, particularly in the manufacturing and tourism-related sectors, indicate that these two sectors hold potential for further development in the future. Such development can be expected to increase the employment opportunities and in turn increase the social economic welfare of people within Gianyar district. 
The Development of LPD of Gianyar District

The Village Credit Institutions (Lembaga Perkreditan Desa or LPD) are community-based financial institutions (microfinance institutions) that are owned, managed and used by the members of the custom village (desa adat) in Bali (Government of Bali 1988). The first LPD was established in 1984 and many more followed in the following years. The objectives of establishing an LPD in each custom vil- lage are to support rural economic development through enhancing savings behavior of rural people and providing credit for small-scale enterprise, to eliminate exploitative forms of credit relations, to create an equal opportunity for business activities at the village level, and to increase the degree of monetization in rural areas (Government of Bali 2002). These objectives reflect the development mission of the LPDs to provide financial service for rural people in Bali.

Table 4.General indicators of Village Credit Institutions (LPDs) within Gianyar District of Bali Province 1999-2001

\begin{tabular}{|c|c|c|}
\hline General Indicators & 1999 & 2001 \\
\hline \multicolumn{3}{|c|}{ Information on the Village Credit Institutions (LPD): } \\
\hline Number of LPDs & 142 & 174 \\
\hline Number of staff & 723 & 873 \\
\hline * Total assets (billion Rp) & 58 & 125 \\
\hline * Total equity (billion Rp) & 10.9 & 25.4 \\
\hline * Total profit (billion Rp) & 4.4 & 10.2 \\
\hline \multicolumn{3}{|l|}{ Lending and savings activities: } \\
\hline Volume of loans outstanding (billion Rp) & 36 & 89 \\
\hline Number of borrowers & 36,454 & 49,593 \\
\hline * Average loans size per borrower (000 Rp) & 954 & 1,603 \\
\hline Volume of time deposits (billion Rp) & 23 & 47 \\
\hline Number of time deposits account (depositors) & 6820 & 7948 \\
\hline Average deposit per depositor (million Rp) & 3.5 & 5.7 \\
\hline Volume of savings (billion Rp) & 22.5 & 50 \\
\hline * Number of savings account (savers) & 81,178 & 114,994 \\
\hline Average savings per saver (000 Rp) & 243 & 415 \\
\hline Bank deposits in Bank BPD Bali (billion Rp) & 20 & 29 \\
\hline \multicolumn{3}{|l|}{ Financial intermediation indicators: } \\
\hline Deposits to loan ratio (DLR) in \% & 111 & 106 \\
\hline - Savers and depositors to borrowers ratio (\%) & 241 & 248 \\
\hline
\end{tabular}

Source: Financial Report of LPD Gianyar District of Bali Province 1999 and 2001 (PLPDK 1999; PLPDK 2001) (computed by the author). 
In Gianyar district of Bali, the first Village Credit Institution (LPD) established was LPD Manukaya, as one of LPD pilot projects, which is located in the custom village of Manukaya in 1984. Subsequently, the growth of LPD in Gianyar district has been very fast. On the one hand, the rapid rise of LPDs is due the increasing demand of Balinese for rural financial institutions since the institutions have been able to meet their needs for an easy access for credit (Arsyad 2005). On the other hand, the provincial government of Bali and Bank BPD Bali actively support the establishment of new LPDs by funds provision as an initial capital and supervision for the establishment of the LPDs. The provincial government of Bali plans to set up one LPD in each of the 1,600 custom village.

As seen in Table 4, at the end of 2001, it has been recorded that 174 LPDs have been established in Gianyar district, and they were spread over all of the seven subdistricts. These LPDs together employ 873 employees directly. In terms of asset development, the LPDs of Gianyar have also experienced a remarkable growth. Table 4 also shows that in only two years between 1999 and 2001, total assets increased almost 2.5 times from Rp58 billion to Rp125 billion. This growth was mainly caused by the growth of loans outstanding that more than doubled from Rp36 billion in 1999 to Rp89 billion in 2001. In addition, establishment of new LPDs also has increased the total assets.
Meanwhile, its equity also more than doubled from Rp10.9 billion in 1999 to Rp25.4 billion in 2001. Equity here refers to value to invested capital (initial investment) plus retained earnings. The increasing equity resulted from the increase of retained earnings (total profit). As shown in Table 4, total profit of the LPDs has increased from Rp4.4 billion in 1999 to Rp10.2 billion in 2001. In addition to the profit, the initial investment for new establishments of the LPDs also has raised the total equity.

The main activity of the LPDs is lending-savings activity for mainly small-scale entrepreneurs, small traders, and farmers. The volume of loans outstanding also rapidly increases from year to year. The data in Table 4 shows that in 1999 the volume of loans outstanding has been Rp36 billion and in 2001 this amount increases to Rp89 billion. Moreover, other than the volume of loans outstanding, the number of borrowers also increases from 36,454 borrowers to 49,593 borrowers in the same period.

The development indicators of LPDs from deposits side are savings and time deposits. Both savings and time deposits are very high, not only in terms of the value of funds generated, but also in terms of the number of savers and depositors. Table 4 shows that the total amount of funds generated from the clients through savings and time deposits exceeded the total amount of loans outstanding in 1999 and 2001. In 1999 the generated funds from the clients was Rp45.5 billion 
while the total of loans outstanding was Rp36 billion. In 2001 these amount increase to Rp97 billion and Rp89 billion respectively. Table 4 also shows that the number of savers and depositors also exceeded the number of borrowers in 1999 and 2001. In 2001, the number of borrowers of 49,593 was much lower than the number of savers and depositors accounts of 122,942 . These high growths of number of borrowers, outstanding loans, savings and deposits are evidence of strong client demand.

The figures above will in turn affect the deposits to loans ratio(DLR) and savers (and depositors) to borrowers ratio. Table 4 shows that these two ratios were higher than 100 percent and the most remarkable thing is that the savers and depositors to borrowers ratio exceeded 200 percent in 1999 and 2001. This phenomenon implies that the LPDs in Gianyar have succeeded in achieving their role as financial intermediaries and to enhance their outreach, which is a proxy of its positive impact on rural economic development.

\section{Portfolio Quality, Leverage, and Capital Adequacy}

Portfolio quality, particularly, the repayment rate is the most important performance indicator of microfinance institution since it has a large bearing on whether a microfinance institution is likely to be self-sufficient and sustainable in the long run (Christen 1998; Sharma and Zeller 1997; Woolcock
1999; Yaron 1994; Zeller 1998). Yaron (1994) argues that a high profit earned by microfinance institutions cannot be used as the only indicator of selfsustainability of the institutions, since a high profit could be attained just in the short period only. Attaining a high rate of loan collection (repayment rate) is a necessary condition for a microfinance institution to become self-sustainable in the long run. Loan losses often have been the largest cost borne by the institutions and the principal cause of insolvency and illiquidity. The importance of the portfolio quality indicator is also reflected in the healthiness criteria of banking institution set up by the Central Bank -the socalled CAMEL criteria- that gives a high weight of thirty percent for this indicator (Bank Indonesia 1997 ).

In this study, portfolio quality performance is assessed using two indicators, that is, repayment rate and delinquent borrower ratio. According to Bank BPD Bali (2000), the loans portfolio of LPD is classified into four categories: pass, doubtful, substandard, and loss. In this study the repayment rate refers to the ratio between the first three categories of outstanding loans divided by total outstanding loans (all four categories) and delinquent borrower ratio refers to the number of borrowers who do not repay their loans until past due relative to total borrowers. Based on the data in Table 5, the LPDs within Gianyar district perform a good portfolio quality, which is reflected by its high repayment rate and low delinquents borrowers ratio. 
Arsyad -An Assessment of Microfinance Institution Performance

Table 5. Portfolio Quality, Leverage, and CAR of LPDs within Gianyar District of Bali Province 1999 and 2001 (means)

\begin{tabular}{|c|c|c|}
\hline Indicators & 1999 & 2001 \\
\hline Portfolio quality: & & \\
\hline Repayment rate (\%) & 95 & 97 \\
\hline Delinquent borrowers ratio (\%) & 0.5 & 0.4 \\
\hline $\begin{array}{l}\text { *everage } \\
\text { (Debt to Equity Ratio) in \% }\end{array}$ & 220 & 210 \\
\hline * Capital adequacy ratio (CAR) in \% & 31 & 61 \\
\hline
\end{tabular}

Source: Financial Report of LPD Gianyar District of Bali Province 1999 and 2001 (PLPDK 1999; PLPDK 2001) (computed by the author).

There are four interrelating reasons that could explain the good portfolio performance. Firstly, in accordance with its regulation, an LPD only gives loans to the clients who have their own business, such as small-scale industry entrepreneurs, farmers, or small traders. The credit should be used for productive economic activities purposes (Government of Bali 2002). For the LPDs management, it is relatively easy to identify the credit applicants whether or not they have business activities since the operational area of each LPD is limited in a custom village in which most of the people know each other. As a result, this could positively influence their repayment ability. The use of village agents, such as custom village leader in Bali, in screening potential borrowers and collecting repayment would help to mitigate the information problems that hamper the performance of microfinance institutions when lending to small entrepreneurs (Arsyad 2005;
Chaves and Gonzales-Vega 1996; Fuentes 1996; Onchan 1992; Timberg and Aiyar 1984; Yaron 1992). In addition, by gaining access through the agent to village-level enforcement mechanisms such as social sanctions, the microfinance institution may also mitigate some of the problem it faces when collecting repayment.

Secondly, most of the borrowers are from the custom village where the LPD is located. The LPDs are rooted culturally and legally to the custom village community (Government of Bali 1988). The LPDs are community financial institutions which are owned, managed, and used by the members of the custom village. This embeddedness of the LPDs within its local institutions has caused the clients' sense of belonging of their LPD and moral obligation to help the development of their LPD (Arsyad 2005). Moreover, in credit mechanism including screening process and contractual enforcement, the LPDs management cooper- 
ates with the Board of Commissioners (Dewan Pengawas)-led by the custom village leader (Bendesa Adat) - who knows the character (reputation) of the clients well. The use of this informal institution has been comparatively efficient in avoiding costly mistakes in assessing the probability of loan repayment.

Thirdly, the custom (social) sanctions - that could be applied in accordance with the written custom village regulations (awig-awig) - have forced the borrowers to repay their credits timely. According to the interviews and Oka (1999: 17), the custom village regulation has been effective in overcoming the problem of delinquent borrowers or low repayment rate. Finally, the LPDs staff members have a high mobility in respect to collecting loan repayments. A LPD staff member visits the clients in their houses (mobile banking techniques) to collect savings deposits and loan repayments in person. This system has also forced the clients to repay their loans regularly and timely.

In summary, it could be argued that a good portfolio quality performance of LPDs is affected by practical arrangement of LPD management using social custom regulation which includes social norms, sanctions, and involvement of custom village leader in screening process and contractual enforcement of loan (informal institutions), regulations set up by the Central Bank (formal institutions), and the mechanism of collecting loan repay- ments applied by the LPDs management.

Leverage and capital adequacy ratio (CAR) reflects the structure and sufficiency of capital of microfinance institutions. It is argued that sufficient capital is also one of the key factors affecting the healthiness and sustainability of microfinance institutions, since sufficient capital encourages lenders (if the microfinance institutions borrow funds from, for instance, commercial banks) and depositors to have confidence in the microfinance institutions relative to its ability to provide for losses and fund future growth (Ledgerwood 1999).

In this study, the leverage of LPDs is calculated using debt to equity ratio (DER). The LPDs of Gianyar has a relatively high DER of larger than two hundred percent. This high DER was mainly caused by the high value of clients' savings and deposit since the LPDs did not borrow any funds from other institutions. The clients' savings and deposit is classified as a debt in banking or microfinance institutions (Ledgerwood 1999: 224). However, as shown in Table 5, the DER of the LPDs slightly decreased from 220 percent in 1999 to 210 percent in 2001. The decrease of DER in that period was mainly caused by the increase of the equity of the LPDs which was doubled in 2001 as shown in Table 5. The increasing trend of equity indicates that the LPDs have been experiencing an improved capital structure that in turn could enhance their the 
ability to be sustainable microfinance institutions.

Concerning the leverage, Ledgerwood (1999: 224) argues that any microfinance institution has to maintain a proper balance between debt and equity to ensure that the equity or viability of the institution is not at risk. Further, she argues that when a microfinance institution (such as the LPDs) has a large amount of equity and very little debt, it is likely limiting its income-generating-potential by not making use of external sources of debt. In this respect, the LPDs have chosen a profitable way, by offering a line of credit or a loan that can be borrowed for 0.8 percent (for savings) and 1.3 percent (for time deposit) monthly, and onlent the generated funds (savings and time deposit) to the clients in therange of 2.25-2.75 percent monthly. Therefore, as Ledgerwood (1999) states, it may be better for a microfinance institution to increase its liabilities (in particular savings and time deposits), when it is possible to increase its income-generating assets (its loan portfolio), and this is the case with the LPDs.

According to banking regulations (formal institutions), there is no restriction on the leverage (DER) of any microfinance institution in Indonesia, including the LPDs. However, there is a regulation from the Central Bank (Bank Indonesia 1997) that any microfinance institutions has to main- tain the loan to deposit ratio (LDR) around 95 percent and the minimum capital adequacy ratio (CAR) of 10 percent to ensure the security of the clients' savings (including their deposits) and the viability of the institution.

Based on the capital adequacy ratio (CAR), ${ }^{10}$ the LPDs of Gianyar also show a good performance. Table 5 shows that LPDs have a high CAR which remarkably increased from 31 percent in 1999 to 61 percent in 2001. This figure is very much higher than the minimum CAR of 10 percent for a healthy microfinance institution set up by the Central Bank (Bank Indonesia 1997). Like the decreasing trend in DER, the increasing trend in the CAR of LPDs is mainly caused by the rapid growth in the equity. The increasing trend of CAR resulting from the rapid growth of equity supports the previous findings that the potentiality of LPDs to be a self-sustained microfinance institution is high.

\section{Productivity and Efficiency}

Productivity refers to the volume of business that is generated (output) for a given resource or asset (input), while efficiency refers to the cost per unit of output. Based on those two indicators the LPDs within Gianyar district also show a good performance. Its productivity indicators, which are measured by several indicators (see

\footnotetext{
${ }^{10} \mathrm{CAR}$ refers to the level of capital required to absorb potential losses while providing financial sustainability. The calculation method of CAR is presented in Appendix 1.
} 
Gadjah Mada International Journal of Business, September-December 2005, Vol. 7, No.3

Table 6. Productivity and Efficiency of LPDs within Gianyar District of Bali Province 1999 and 2001 (means)

\begin{tabular}{|c|c|c|}
\hline Indicators & 1999 & 2001 \\
\hline \multicolumn{3}{|l|}{ Productivity: } \\
\hline - Number of borrowers per staff & 49 & 67 \\
\hline - Loans outstanding per staff (million Rp) & 48 & 67 \\
\hline - Number of savers per staff & 108 & 111 \\
\hline - Savings per staff (million Rp) & 31 & 34 \\
\hline - Number of depositors per staff & 9 & 8 \\
\hline - Time deposits per staff (million Rp) & 31 & 35 \\
\hline \multicolumn{3}{|l|}{ Efficiency: } \\
\hline - Operating cost ratio & 0.20 & 0.22 \\
\hline $\begin{array}{l}\text { - Salaries as a percentage of average } \\
\text { portfolio outstanding }\end{array}$ & 0.006 & 0.008 \\
\hline
\end{tabular}

Source: Financial Report of LPD Gianyar District of Bali Province 1999 and 2001 (PLPDK 2001; PLPDK 1999) (computed by the author).

Table 6), reveal an increasing trend between 1999 and 2001, which means the productivity of its staff increased during this period. Productivity per staff member, which is reflected by the workload of the average staff member, increased from 108 to 125 savers per staff in 1999 and 2001 respectively. On the other hand, this increase could augment the burden of the staff particularly in monitoring the clients and enforcing the contractual agreement with the clients to keep a good repayment rate.

The size of savings and time deposits per staff member has also increased from Rp31 million in 1999 to over Rp50 million in 2001. Meanwhile, the average loans outstanding managed per staff member has almost doubled from Rp48 million in 1999 to
Rp93 million in 2001. In some studies the productivity indicators were sometimes treated as outreach indicators (Yaron 1992; Yaron 1994; Yaron et al. 1998). Hence, these figures imply that the outreach of the LPDs of Gianyar district has increased in that period.

One internal factor that might contribute to this increasing productivity of the LPDs staff is the remuneration system. Three chairmen of LPDs interviewed point out that all management staff is satisfied with the remuneration system which is indicated by the working motivation of the staffs. According to the three chairmen, the working motivation of the staffs is high. The interviews with the chairmen (interviews 7 and 8 February 2002; $21,23,25,26$ February 2003) revealed that the LPD staff are favorably dis- 
posed to the current remuneration system of basic salary and incentives which they regard as competitive and fair. However, an external factor must also be considered, namely the increase in clients of the LPDs -including borrowers, savers, and depositors- that have forced the staff to serve more clients that in turn increase the productivity and workload of the staff member.

The LPDs' efficiency is measured by two indicators, which are operating cost ratio that refers to operating costs relative to the average portfolio outstanding and salaries as a percentage of average portfolios outstanding. Based on those two indicators as shown in Table 6 , it could be concluded that LPDs are efficient. The data in the Table shows that their operating cost ratio was 20 percent and 22 percent in 1999 and 2001 respectively. This means that the LPDs fully covered the cost day-to-day operations, including salaries and administrative costs, with revenues from interest. The revenues of LPDs are gained almost exclusively from lending, with loanable funds derived from savings and time deposits, since most of them do not have any business activity other than lending and saving activities. Based on a study of USAID in several developing countries (Indonesia, Bangladesh, Bolivia, Senegal, Dominica, Costa Rica, Colombia, and Niger), successful microfinance institutions tend to have operating cost ratios of between 13 and 21 percent of their average loan portfolios (Christen et al. 1995). Com- pared to the other developing countries, the operating cost ratio of LPDs is close to upper end of the range, meaning that the LPDs are still efficient.

Meanwhile the salaries ratio of LPD is extremely low around 0.7 percent. Christen et al. (1995) state that the ratio of many successful microfinance institutions lies between 4 to 16 percent of average portfolio outstanding. This low salary cost is partly because the LPDs use local community personnel as their staff in managing the LPD and the local cost of living as determining factor for the basic salary. Furthermore, the local government (formal institutions) regulates the remuneration system of the LPD's staff, which is a function of financial capacity (profits and loan instalment recovered) of the LPD, and thus is observable and measurable.

This high efficiency of LPDs could be attributed to two main factors. Firstly, low transaction costs. The LPDs have applied a flexible arrangement in delivery mechanism. As local and user-owned financial institutions whose operational coverage of a small area of custom village allow the LPDs management to have an intimate knowledge of their clients and harness mechanisms of social control in screening and contractual enforcement process. This mechanism has reduced and minimized the transaction costs for both lender and borrower. Secondly, low salary cost. The remuneration system which is based on the local cost of living and financial capacity (profits 
and loan instalment recovered) of the LPDs has also contributed to the high efficiency of the LPDs.

\section{Profitability and Financial Viability}

Ledgerwood(1999) points out that profitability and efficiency are key factors shaping the financial viability (operational and financial self-sufficiency) of a microfinance institution. Previous section has revealed that the LPDs in Gianyar district are efficient. This section deals with the profitability and financial viability which would influence the sustainability of microfinance institution.

By using the consolidated financial reports of LPDs of Gianyar district, it is found that the LPDs have been profitable. The evidence that LPDs are fully profitable lies in the positive adjusted returns on assets (ROA) and return on equity (ROE). Table 7 shows that the adjusted ROA increased from 10 percent in 1999 to 13.5 percent in 2001. The indicators are high enough to gain profit and show a rising trend from 1999 to 2001 . Compared to the adjusted ROA of LPDs at provincial level of 7.4 percent (Christen et al. 1995), this figure is higher.

The adjusted ROE experienced a high growth from 23 percent in 1999 to 51 percent in 2001. These figures are much higher than the inflation rate of 10.3 and 11.4 percent per annum in the same period. They are also much higher than the time deposit interest rate of commercial banks which was around 14-16 percent in that period. When we consider the time deposit interest rates of commercial banks as the opportunity of the LPDs, this number implies that the LPDs have been sustainable according to the definition of microfinance sustainability (Yaron 1994).

However, in a comparative context, this figure is slightly lower than the ROE of the LPDs at the provincial

Table 7. Profitability and Financial Viability of LPDs within Gianyar District of Bali Province 1999 and 2001 (means)

\begin{tabular}{|c|c|c|}
\hline Indicators & 1999 & 2001 \\
\hline \multicolumn{3}{|l|}{ Profitability: } \\
\hline - Adjusted Return on Asset (ROA) in \% & 10 & 13.5 \\
\hline - Adjusted Return on Equity (ROE) in \% & 23 & 52 \\
\hline \multicolumn{3}{|l|}{ Financial viability: } \\
\hline - Operational self-sufficiency (\%) & 199 & 196 \\
\hline - Financial self-sufficiency (\%) & 181 & 163 \\
\hline
\end{tabular}

Source: Financial Report of LPD Gianyar District of Bali Province 1999 and 2001 (PLPDK 1999; PLPDK 2001) (computed by the author). 
level of 54.2 percent calculated by Chaves and Gonzales-Vega (1995), but it is still higher than the calculation of Christen et al (1995) of 32.7 percent per annum. This difference might be caused by different method of calculation and period. Compared to the ROE of BKK of 13 percent (Yaron 1992) which have similar characteristics with the LPDs, the figure is much higher.

In sum, the growth of those two profitability indicators (ROA and ROE) indicates that the LPDs have been able to perform as a profitable and sustainable microfinance institution. Three internal factors might contribute to this high profitability rate. First, the high level of efficiency of the LPDs, as discussed earlier, obviously contributed to this high profitability. Second, the high growth of clients deposits (savings and time deposit), accompanied by the high growth of loans disbursed, also plays a role in the profitability of the LPDs. Even though the high growth of clients' deposits of the LPDs has resulted in high DER, the LPDs were able to on-lend the deposits to its clients and generate income. In addition, when the LPDs experience excess liquidity they have to deposit their excess liquidity to Bank BPD Bali and receive a competitive interest rate (Government of Bali 1988). Third, the high repayment rate of the LPDs greatly contributed to the high profitability. This high repayment rate maintains the liquidity of the LPDs and then sustains the ability of LPDs to on-lend the generated funds to its clients. Finally, the external factor that has supported the LPDs to gain their high profitability is macroeconomic environment. A stable and growing macroeconomic condition of Gianyar district has enabled the LPDs to attain the high profitability rate. According to Statistics of Bali Province 2001, during Indonesian economic crisis from 1997 until 1999, the Gianyar economy still experienced a positive economic growth. Gianyar economic growth rates were 6 and 4.5 percent per annum in 1997 and 2001 respectively. Its economic growth rate in 2001 was higher than Bali and national average growth rate of 3.4 and 3.3 percent per annum respectively.

Financial viability refers to the ability of LPD to cover its costs with earned revenue. Two indicators of financial viability used are operational self-sufficiency and financial self-sufficiency (Ledgerwood 1999). Operational self-sufficiency indicates the ability of LPD to earn enough revenue to cover its direct costs, excluding the (adjusted) cost of capital but including actual financing costs incurred. Financial self-sufficiency indicates the ability of LPD to earn enough revenue to cover both direct costs, including financing costs, provision for loan losses, an operating expenses, and indirect costs, including the adjusted cost of capital. In this study, the adjusted cost of capital is considered the cost of maintaining the value of equity relative to inflation. The indicators of financial viability are also presented in Table 5 . 
The level of financial viability of the LPDs shows an increasing trend. In 1999 and 2001, the level of operational self-sufficiency was 199 percent and 196 percent respectively, whereas the level of financial selfsufficiency was 181 percent and 163 percent in the same period. These levels of self-sufficiency are higher than the calculation of Christen et al. (1995), which were 148 percent and 137 percent for operational and financial selfsufficiency respectively. Combined with other financial indicators discussed above, the increasing trend of operational and financial self-sufficiency evidently indicates that the LPDs have been financially viable, which is one of the necessary conditions for a sustainable microfinance institution.

There are three internal interrelated factors explaining this high financial viability which are high profitability, high efficiency, and good portfolio quality or high repayment rate. As discussed above, the high level of efficiency of the LPDs has resulted in the high profitability. In literature, it is argued that the efficiency and profitability are the main factors shaping self-sufficiency of microfinance institution (Ledgerwood 1999: 217). More specifically, Christen et al (1995) argue that the levels of self-sufficiency have been very much affected by the effective real interest rate charged by a microfinance institution which, in turn, affects the profitability of the institution. The LPDs charge an interest rate of around 0.8-1.3 percent monthly for savings (and time deposits) and 2.252.75 percent monthly for lending rate. These figures show that the LPDs have set up an effective real rate of interest high enough to cover their costs, including the cost of capital fully adjusted for inflation. Lastly, good portfolio quality or high repayment rate has contributed to the self-sufficiency of LPDs both directly through its effect on the profitability and indirectly through its effect on the liquidity and net income of LPDs. As noted earlier, attaining a high repayment rate is a necessary condition for a microfinance institution to become self-sustainable in the long run.

\section{Outreach}

As noted earlier, some scholars (Schreiner 2001; Yaron 1994; Yaron et al. 1997) point out that outreach indicators could be used as indicators of the impact of microfinance institutions on economic development. They argue that even though the indicators do not provide a full assessment of a microfinanceinstitution impact on economic development, they serve as quantifiable proxies of the extent to which a microfinance institution has reached its objectives of providing social benefits for poor people. Hence, the outreach indicators have to be considered in the context of the objectives of microfinance institution, which define its target clientele. These indicators are classified into three groups: client and staff, loan, and savings/deposit outreach (Table 8 ). 
Arsyad -An Assessment of Microfinance Institution Performance

Table 8. Outreach of LPDs within Gianyar District of Bali Province 1999 and 2001

\begin{tabular}{|c|c|c|}
\hline Indicators & 1999 & 2001 \\
\hline \multicolumn{3}{|l|}{ Clients and Staff outreach: } \\
\hline Number of borrowers & 36,454 & 49,593 \\
\hline - Average borrowers per LPD & 309 & 324 \\
\hline - Number of savers & 81,178 & 114,994 \\
\hline - Average savers per LPD & 695 & 751 \\
\hline - Number of deposit accounts (depositors) & 6820 & 7948 \\
\hline - Average depositor per LPD & 60 & 52 \\
\hline - Number of staff & 723 & 835 \\
\hline - Average number of staff per LPD & n.a. & 5 \\
\hline $\begin{array}{l}\text { - Percentage of total target } \\
\text { clientele serviced }(\%)\end{array}$ & 10.3 & 13.4 \\
\hline \multicolumn{3}{|l|}{ Loan outreach: } \\
\hline - Volume of outstanding loans (billion Rp) & 36 & 89 \\
\hline - Average outstanding loan per LPD (million Rp) & 308 & 587 \\
\hline - Average loans per borrower (million $\mathrm{Rp}$ ) & 0.9 & 1.6 \\
\hline $\begin{array}{l}\text { Average loans per borrower as } \\
\text { percentage of GRDP per capita* }\end{array}$ & 0.21 & 0.27 \\
\hline \multicolumn{3}{|l|}{ Saving/Deposits outreach: } \\
\hline - Volume of savings (billion Rp) & 22.5 & 50 \\
\hline - Average savings per LPD (million Rp) & 198 & 327 \\
\hline $\begin{array}{l}\text { - Average savings per saver as proportion } \\
\text { of GRDP/capita* }\end{array}$ & 0.05 & 0.07 \\
\hline Volume of time deposits (billion Rp) & 22 & 46 \\
\hline - Average deposits per LPD ((million Rp) & 221 & 335 \\
\hline $\begin{array}{l}\text { Average deposit per depositor } \\
\text { as proportion of GRDP/capita* }\end{array}$ & 0.7 & 0.9 \\
\hline
\end{tabular}

Note: * GRDP per capita of Gianyar district at current price in 1999 and 2001 were Rp 4.6 million and $\mathrm{Rp} 5.8$ million respectively.

n.a. $=$ not available

Source: Financial Report of LPD Gianyar District of Bali Province 1999 and 2001 (PLPDK 1999; PLPDK 2001) (computed by the author). 
Gadjah Mada InternationalJournal of Business, September-December 2005, Vol. 7, No.3

As shown in Table 8, the LPDs experienced an increasing trend for almost all outreach indicators, except average depositor per LPD. The scale of outreach, for instance, measured by the number of clients served and the volume of outstanding loans and savings, have grown significantly in the period of 1999 to 2001. In 1999, the total number of borrower was 36,454 while the total number of savers and depositors was 87,998 and these figures increased to 49,593 and 122,942 respectively in 2001. Along with the client growth, the volume of outstanding loans has also increased almost 1.5 times from Rp36 billion in 1999 to Rp89 billion in 2001. Meanwhile, the volume of savings and time deposits has increased more than 100 percent from Rp44.5 billion in 1999 to Rp96 billion in 2001.

The figures in the Table 8 show that, firstly, the total clientele served in terms of savers and depositors was higher than the total clientele served in terms of borrowers and, secondly, the volume of loan outstanding is lower than the volume of total savings and time deposit. There are two important things worth noting from these figures. First, the figures indicate that the LPDs have succeeded to stimulate and enhance the savings behavior of rural people. In addition, this situation shows that the LPDs have achieved one of their objectives, which is to increase particularly banking mindedness of rural people and the degree of monetization in rural areas in general (Government of Bali 2002). Second, the figures also indicate that the LPDs have succeeded to offer an appropriate mechanism in mobilizing savings such as mobile banking system, interest rates, and other incentives for savers and potential savers.

The clients of LPDs (interviews on 22 and 23 February 2002) point out that the LPDs delivery mechanisms have met their needs. Moreover, it can be argued that this situation also implies that the clients' confidence on the LPDs has been high, since the savings security is an important consideration for the clients in making a decision to save or not to save in any financial institution (Arsyad 2005). This finding also confirms to the findings of other studies (Adams 1978; Kelley and Williamson 1968; Robinson 1994) which reveal that rural people-including household, smallscale enterprises, organizations- will save in a financial form if appropriate institutions are offering security, convenience, liquidity, and returns on savings. The ability of microfinance institutions - the LPDs in this case- to meet the needs of the local people that they are designed to help will, in turn, be one of the advantages of the LPDs to be a sustainable microfinance institution (Snow 1999, p. 66). From an institutional point of view, incorporating savings mobilization in microfinance institutions will have at least three benefits for the institutions (Robinson 1995). First, it can provide a relatively inexpensive source of capital for relending. Second, today's depositors may be tomorrow's borrowers, so the 
savings program creates a natural client pool. Third, building up savings may offer important advantages to lowincome households directly: households can build up assets to use as collateral, they can build up a reserve to reduce consumption volatility over time, and they may be able to selffinance investments rather than always turning to creditors.

The depth of outreach is shown by target clientele (borrowers) serviced, average loan/savings/time deposits per borrower, and the ratio of the average loans per borrower, average savings per saver, and average time deposits per depositor to GRDP per capita. The depth of outreach indicators reflect the value that society attaches to the net gain of a given client (Schreiner 2002: 594).

The data in the table reveals that target clientele served has increased from 10.3 percent in 1999 to 13.4 percent in 2001. Along with the increase in the target client served, the average loan per LPD has also increased from Rp308 million in 1999 to Rp587 million in 2001 and the average savings and time deposits per LPD increased from Rp198 million and Rp221 million in 1999 to Rp327 million and Rp335 million in 2001. These figures reflect that the LPDs have also reached one of its objectives, that is, to support rural economic development through providing credit to local people.

The ratio of the average loans per borrower, average savings per saver, and average time deposits per deposi- tor to GRDP per capita have also increased along with the increase of their percentages of GRDP per capita. These figures indicate that both the economic capacity and banking mindedness of the clients and financial capability of LPDs in providing financial services have also increased in line with the growth of GRDP per capita (economic growth) in Gianyar district of Bali. In other words, the figures also indicate that the LPDs have yielded social benefits for their clients.

Referring to the objectives of LPDs (Government of Bali 2002), all of these figures indicate that the LPDs have been able to achieve their objectives, which are to support rural economic development through enhancing savings behavior of rural people and providing credit for local people, to create an equal and opportunity for business activities in the village level, and to increase the degree of monetization in rural areas. Hence, it can be argued that the LPDs have had some positive impacts on rural economic development in Gianyar district of Bali.

In sum, the growth of the outreach indicators of LPDs indicates that the LPDs have yielded social benefits for their clients and, hence, played an important role in rural economic development in Gianyar district of Bali. There are four factors shaping the growth described above. Firstly, the ability of LPDs management to offer an appropriate deliverymechanism that meet and suit to the needs of the local people. Secondly, an increasing number of staff and its productivity, as 
discussed earlier, also contribute to this growth. Thirdly, the social ties of LPDs to their clients in a custom village that shared social and religious norms has encouraged high clients' reliance and loyalty (sense of belonging) on the LPDs and, in turn, influenced the outreach of LPDs (Arsyad 2005). Finally, the growing macroeconomic condition of Gianyar district has also contributed to the growth of outreach of the LPDs. It is argued that a growing economy has resulted in high and growing demands for financial services offered by financial institutions (Chaves and Gonzales-Vega 1996; Franks 2000; Robinson 2001), such as LPDs, that in turn affect their outreach as well.

\section{Conclusion}

First, based on the analysis above it can be concluded that the LPDs in Gianyar district have a good performance and could be considered as success microfinance institutions. The performance indicators assessed include portfolio quality, leverage, capital adequacy ratio (CAR), productivity, efficiency, profitability, self-sufficiency, and outreach. Based on the necessary conditions of sustainable microfinance institution proposed by some scholars (Christen 1998, Yaron 1994), it can be concluded that the LPDs of Gianyar district have been sustainable. This also implies that the LPDs have positive net social benefits for their clients. As argued by some scholars (Ostrom et al. 1993: 13-14), when a micro- finance institution becomes sustainable, net social benefits will be positive. Hence, the positive impact of the LPDs on their target clientele indicates that the role of LPDs as a development tool has been evident in economic development of Gianyar district.

Second, the good performance and sustainability of the LPDs has been influenced by both formal and informal institutions, and a growing economy of Gianyar district. The influence of formal institutions that is reflected by supporting government policy at all levels through provision of a legal basis for the LPDs and the Central Bank regulation (formal institutions) as also pointed by Arsyad (2005) have contributed to the success of the LPDs in Gianyar district.

The influence of informal institutions is indicated in several aspects. Firstly, the use of local people in managing LPD and the application character-based lending system in credit delivery system. As mentioned earlier, the LPDs are community financial institutions which are owned, managed, and used by the members of a custom village. This has resulted in a high clients' sense of belonging and moral obligation to support the development of LPD. Secondly, the use of social (custom) sanctions in contractual enforcement has forced the borrowers to comply with their credit contract in a timely fashion. Thirdly, the use of mobile banking technique for collecting savings deposits and loan repayments directly has also compelled the clients 
to repay their loans regularly and timely. Fourthly, the use of local community personnel in its operations whose remuneration is based on performance and low transaction costs has resulted in a high efficiency of LPDs. This high efficiency in turn has fostered a high profitability and selfsufficiency of LPDs. Lastly, the high outreach level of LPDs accompanied by a high clients' loyalty has a positive impact on the sustainability of the LPDs. As argued by Christen (1998), one of the most important factors affecting the self-sustainability of microfinance institutions is a high outreach level. Last but not least, a stable and growing economy of Gianyar district has also offered an auspicious climate for the LPDs to develop and to have a good performance.
In sum, the findings of this study reveal the important role of the socioeconomic environment (particularly institutional environment) on the sustainability of microfinance institutions. Practically, however, any attempt to replicate the achievements of the LPDs by imitating their mode of operations should be conducted with great caution. A mechanism that works well in one socioeconomic environment (in this instance, in Bali) will not necessarily work in another, where the social system such as custom, social norms, and values are different. However, the experience of the LPDs has highlighted some critical issues that should be considered when handling the complex issue in providing financial services to the rural people.

\section{References}

Adams, D. W. 1978. Mobilizing household savings through rural financial markets. Economic Development and Cultural Change 26 (3): 547-560.

ADB. 2000. Finance for the Poor: Microfinance Development Strategy. Manila: Asian Development Bank.

Arsyad, L. 2005. Institutions do really matter: Important lessons from village credit institutions of Bali. Journal of Indonesian Economy and Business (JEBI) 20 (2): 105119.

Bank Indonesia, 1997. Circular Letter of Bank Indonesia No.30/3/UPPB. Jakarta: Bank Indonesia.

Bank Indonesia, and GTZ. 2000. Legislation, regulation and supervision of microfinance institutions in Indonesia. Project ProFI. Jakarta: Bank Indonesia.

Berg, B. L. 1998. Qualitative Research Methods for the Social Sciences (3rd ed.). Boston: Allyn and Bacon. 
Gadjah Mada InternationalJournal of Business, September-December 2005, Vol. 7, No.3

Brinkerhoff, D. W., and A. A. Goldsmith. 1992. Promoting the sustainability of development institutions: A framework for strategy. World Development 20 (3): 369-383.

CBS ofBali. 2001. Bali in Figures 2001. Denpasar, Bali: Central Board of Statistics (CBS) of Bali Province.

CBS of Gianyar. 2000. Gianyar in Figure 2000. Gianyar: Central Board of Statistics (CBS) of Gianyar District.

CGAP. 2001. Resource guide to microfinance assessments. CGAP Focus Note No. 22. Washington, D.C.: The Consultative Group to Assist the Poorest (CGAP).

Chaves, R. A., and C. Gonzales-Vega. 1996. The design of successful rural financial intermediaries: evidence from Indonesia. World Development 24 (1): 65-78.

Christen, R. B., E Rhyne, and R. Vogel. 1995. Maximizing the outreach of microenterprise finance: the emerging lessons of successful programs. Focus Note 2. Washington, D.C.: CGAP.

Christen, R. P. 1998. Keys to financial sustainability. In Kimenyi, Mwangi S., Robert C. Wieland, and J. D. Von Pischke(editors) Strategic Issues in Microfinance. Aldershot, England: Ashgate.

Franks, J. R. 2000. Macroeconomic stabilization and the microenterpreneur. Journal of Microfinance 2 (1): 69-89.

Fuentes, G. A. 1996. The use of village agents in rural credit delivery. The Journal of Development Studies 33 (2): 188-209.

Fuller, D., and L. Parker. 2002. Indigenous Economic Development in Northern Australia. Rockhampton: Central Queensland University Press.

Geertz, H., and C. Geertz. 1975. Kinship in Bali. Chicago: The University of Chicago Press.

Government of Bali, Provincial. 1988. The Bali Provincial Regulation No. 2/1988 on Village Credit Institutions.

Government of Bali, Provincial. 1986. The Bali Provincial Regulation No. 6/1986 on the Status, Function, and Role of Custom Village.

Government of Bali, Provincial. 2002. The Bali Provincial Regulation No. 8/2002 on Village Credit Institutions.

Hobart, A., U. Ramseyer, and A. Leemann. 1996. The Peoples of Bali. Oxford: Blackwell Publishers.

Jayasuriya, S. and I. K. Nehen. 1989. Bali: Economic growth and tourism. In Hill, H. (editor) Unity and Diversity: Regional Economic Development in Indonesia since 1970. New York: Oxford University Press, Inc.

Kelley, A. C., and J. G. Williamson. 1968. Household saving behavior in the developing economies. The Indonesian case. Economic Development and Cultural Change 16 (3): 385-403.

Khandker, S. R. 1998. Micro-credit program evaluation: A critical review. Institute of Development Studies Bulletin 29 (4): 1 - 20. 
Arsyad-An Assessment of Microfinance Institution Performance

Ledgerwood, J. 1999. Microfinance Handbook: An Institutional and Financial Perspective. Washington, D.C.: The World Bank.

Mabbet, H. 1985. The Balinese. Wellington, New Zealand: January Books.

Nordholt, H. S. 1991. State, Village, and Ritual in Bali: A Historical Perspective. Amsterdam: VU University Press.

North, D. C. 1991. Institutions. Journal of Economic Perspective 5 (1): 97-112.

North, D. C. 1990. Institutions, Institutional Change, and Economic Performance. Cambridge, MA: Harvard University Press.

Oka, I. G. N. 1999. Peranan awig-awig desa adat dalam operasional LPD(The role of awigawig -custom village regulation-in Operational of LPD). Mimeo. Majelis Pembina Lembaga Adat (Forum for the Development ofCustom Institutions) Propinsi Daerah Tingkat I Bali.

Onchan, T. 1992. Informal rural finance in Thailand. In Adams, D. W., and D. A. Fitchett (editors) Informal Finance in Low-Income Countries. Boulder. Colorado: Westview Press.

Ostrom, E., L. Schroeder, and S. Wynne. 1993. Institutional Incentives and Sustainable Development. Boulder. CO: Westview Press.

PLPDK. 2001. Financial Reports of LPD of Gianyar District. Gianyar: PLPDK (LPD Supervisory Organisation at District Level).

PLPDK. 1999. Financial Reports of LPD of Gianyar District. Gianyar: PLPDK (LPD Supervisory Organisation at District Level).

Rice, R., Herustiati, and A. Junaidi. 2002. Factors affecting the competitiveness of, and impact of the 1997-99 monetary crisis on, selected small and medium manufacturing industries in Central and West Java. Partnership for Economic Growth Project. Jakarta: USAID.

Robinson, M. S. 1995. Indonesia: The role of savings in developing sustainable commercial financing of small and micro enterprises. In Brugger, Ernst A., and S. Rajapatirana (editors) New Perspectives on Financing Small Business in Developing Countries. San Fransisco: ICS Press.

Robinson, M. S. 2001. The Microfinance Revolution: Sustainable Finance for the Poor. Washington, D.C.: The World Bank.

Robinson, M. S. 1994. Savings mobilization and microenterprise finance: The Indonesian experience. In Otero, M., and E. Rhyne (editors) The New World of Microenterprise Finance. Connecticut: Kumarian Press.

Scapens, R. W. 1990. Researching management accounting practice: The role of case study methods. British Accounting Review 22: 259-281.

Schreiner, M. 2002. Aspects of outreach: A framework for discussion of the social benefits of microfinance. Journal of International Development 14: 591-603.

Schreiner, M. 2001. Seven aspects of loan size. Journal of Microfinance 3 (2): 27-47. 
Gadjah Mada InternationalJournal of Business, September-December 2005, Vol. 7, No. 3

Sharma, M., and M. Zeller. 1997. Repayment performance in grouped-based credit programs in Bangladesh: An empirical analysis. World Development 25 (10): 17311742.

Snow, D. 1999. Microcredit: An institutional development opportunity. International Journal of Economic Development 1 (1): 65-79.

Timberg, Th. A., and C.V. Aiyar. 1984. Informal credit markets in India. Economic Development and Cultural Change 33 (6): 43-59.

Warren, C. 1993. Adat and Dinas: Balinese Communities in the Indonesian State. Oxford: Oxford University Press.

Warren, C. 1991. Adat and dinas: Village and state in contemporary Bali.In Geertz, H. (editor) State and Society in Bali. Leiden: KITLV Press.

Woolcock, M. J. V. 1999. Learning from failures in microfinance: What unsuccessful cases tell us about how group-based programs work. The American Journal of Economics and Sociology 58 (1): 17-22.

World Bank. 2002. World Development Report. Washington, D.C.: The World Bank.

World Bank. 2000. World Development Report 2000/2001. Washington, D.C.: The World Bank.

Yaron, Y. 1992. Successful rural finance institutions. World Bank Discussion Papers. Washington, D.C.: The World Bank.

Yaron, Y. 1994. What makes rural finance institutions successful? The World Bank Research Observer 9 (1): 49-70.

Yaron, Y, Mc. D.Benjamin, and S Charitonenko. 1998. Promoting efficient rural financial intermediation. The World Bank Research Observer 13 (2): 147-170.

Yaron, Y., Mc.D. Benjamin, and G. Piprek. 1997. Rural finance: Issues, design, and best practice. Environmentally and Socially Sustainable Development Studies and Monographs Series 14. Washington, D.C.: The World Bank.

Yin, R. K. (2003). Case Study Reseach: Design and Methods. Nebury Park: Sage.

Zeller, M. 1998. Determinants of repayment performance in credit groups: The role of program design, intragroup risk pooling, and social cohesion. Economic Development and Cultural Change 46 (3): 599-620. 
Arsyad-An Assessment of Microfinance Institution Performance

Appendix 1. Calculation Method of Financial Performance Indicators

1. Portfolio Quality
LPPDS
RR : Repayment rate
$R R=\frac{P O}{P O P D S}$
LPPDS : Loan portfolio (pass + doubtful + sub-standard)
PO : Portfolio outstanding (including amounts past due)
$\boldsymbol{D B} \boldsymbol{R}=\begin{array}{lll}\boldsymbol{D B} \boldsymbol{R} & \begin{array}{l}\text { DBR } \\ \text { NDB }\end{array} & \text { : Number of delinquent borrowers } \\ \boldsymbol{T N} \boldsymbol{A} \boldsymbol{B} & \text { TNAB }: \text { Total number of active borrowers }\end{array}$

\section{Productivity and Efficiency Ratios}

The productivity ratios used in this study include number of active borrowers per staff, portfolio outstanding per staff, total amount disbursed in the period per staff, number of active depositors per staff, deposits outstanding per staff, and total amount of savings collected in the period per staff.

Efficiency indicators used in this study are operating cost ratio and salaries as percentage of average portfolio outstanding.

$$
\begin{aligned}
& \boldsymbol{O C R}=-\boldsymbol{O C} \quad \text { OCR : Operating cost ratio } \\
& \boldsymbol{O C R}=\quad \text { OC } \quad \text { :Operating costs } \\
& \text { APO APO : Average portfolio outstanding } \\
& \boldsymbol{S A P A P O}=\frac{\boldsymbol{S A B}}{\boldsymbol{A P O}} \quad \begin{array}{l}
\text { SAPAPO : Salaries as a percentage of average portfolio } \\
\text { outstanding } \\
\text { : Salaries and benefits } \\
\text { APO Average portfolio outstanding }
\end{array}
\end{aligned}
$$

\section{Financial Viability}

To determine financial viability, two self-sufficiency indicators are calculated, which are operational self-sufficiency and financial self-sufficiency.

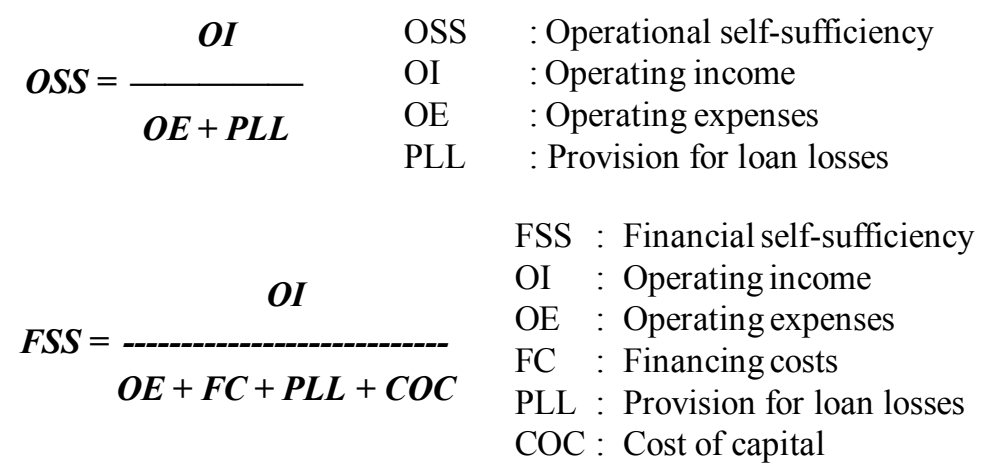


Gadjah Mada InternationalJournal of Business, September-December 2005, Vol. 7, No. 3

4. Profitability Ratios

Two profitability ratio used in this study include return on asset (ROA) and return on equity (ROE).

$\boldsymbol{R O A}=\frac{N I}{A A}$

\section{NAI}

$\operatorname{ROE}($ adjusted $)=$

$$
A E
$$

\author{
ROA: Return on assets \\ NI : Net income \\ AA : Average assets
}
ROE adjusted : Adjusted Return of equity
NAI : Net adjusted income
AE : Average equity

\section{Leverage and Capital Adequacy}

A microfinance institution's leverage is measured bycalculating its debt to equity ratio. The debt to equity ratio states how much debt a microfinance institution has relative to its equity. In this study, debt of LPD consists of savings and time deposits of its clients, since LPD does not borrow any fund from other institutions.

\begin{tabular}{|c|c|c|}
\hline \multirow{3}{*}{$D E R=$} & $\boldsymbol{D}$ & DER : Debt to equity ratio \\
\hline & & $\mathrm{D} \quad$ : Debt \\
\hline & $\boldsymbol{E}$ & : Equity \\
\hline
\end{tabular}

Capital adequacy refers to the amount of capital an MFI has relative to its assets. Capital adequacy relates to leverage in terms of the adequacy of the microfinance institution's funding structure. Capital adequacy means that there is a sufficient level of capital required to absorb potential losses while providing financial sustainability.

Capital adequacy is usually measured by the following ratio of capital to risk-weighted assets:

$$
\boldsymbol{C R} \boldsymbol{W} \boldsymbol{A}=\begin{array}{cll}
\boldsymbol{I} \boldsymbol{C}+\boldsymbol{R}+\boldsymbol{R} \boldsymbol{E} & \text { CRWA }: \text { Capital to risk-weighted assets } \\
& \mathrm{IC} & : \text { Invested capital } \\
\multirow{2}{*}{\boldsymbol{W} \boldsymbol{A}} & \mathrm{R} & : \text { Reserves } \\
& \mathrm{RE} & : \text { Retained earnings } \\
& \text { RWA } & : \text { Risk-weighted assets }
\end{array}
$$

The calculation of Capital Adequacy Ratio (CAR) is based on the ratio of capital to riskweighted assets. For microfinance institutions in Indonesia, as well as the LPDs, as set out by Bank Indonesia (The Central Bank) the capital consists of invested capital (initial capital), provision for loan losses, retained earnings and current profits. Meanwhile, the risk-weighted assets are classified into five categories whose the standard risk weights ranging from 0 percent to 100 percent risk. The first category is cash with 0 percent riskweighted, the second is deposits in Bank BPD of Bali with 20 percent risk-weighted, the third is outstanding loans with 100 percent risk-weighted, the fourth is fixed assets with 100 percent risk-weighted, and the last is other assets with 100 percent risk-weighted. 
Arsyad -An Assessment of Microfinance Institution Performance

Appendix 2. List of Interviewees*

\begin{tabular}{|c|c|c|c|}
\hline No. & Name & Position & Date of Interview \\
\hline 1 & Bagus Sara & Provincial Government Officer & 6 February 2002 \\
\hline 2 & Gusti Arya & Provincial Government Officer & $\begin{array}{l}6 \text { February } 2002 \\
20 \text { February } 2003\end{array}$ \\
\hline 3 & Bagus Sana & Bank BPD Bali Officer & $\begin{array}{l}7 \text { February } 2002 \\
21 \text { February } 2003\end{array}$ \\
\hline 4 & Wayan Weka & Bank BPD Bali Officer & $\begin{array}{l}7 \text { February } 2002 \\
21 \text { February } 2003\end{array}$ \\
\hline 5 & Nyoman Awan & Chairman of LPD Talepud & $7 \& 8$ February 2002 \\
\hline 6 & Made Dana & Chairman of LPD Mas & 21-23 February 2003 \\
\hline 7 & Ketut Awan & Chairman of LPD Kerta & $25 \& 26$ February 2003 \\
\hline 8 & Wayan Jana & $\begin{array}{l}\text { Member of Commissioner } \\
\text { Board of LPD Mas }\end{array}$ & 23 February 2003 \\
\hline 9 & Gde Dana & $\begin{array}{l}\text { Chief of Commissioner Board } \\
\text { of LPD Kerta }\end{array}$ & $25 \& 26$ February 2003 \\
\hline 10 & Ktut Empu & LPD client & 22 February 2002 \\
\hline 11 & Wayan Elin & LPD client & 23 February 2002 \\
\hline 12 & Wayan Arsha & LPD client & 22 February 2002 \\
\hline
\end{tabular}

*Name of interviewees are disguised 